\title{
PENINGKATAN KEMAMPUAN MENULIS PARAGRAF NARASI DENGAN MENGGUNAKAN STRATEGI BRAINSTORMING (PENELITIAN TINDAKAN KELAPADA SISWA KELAS X5 SMA NEGERI I WATANSOPPENG)
}

\author{
Hutbaya \\ SMAN 1 Watansoppeng, Kabupaten Soppeng \\ hutbaya_soppeng@gmail.com.
}

\begin{abstract}
This classroom action research aimed to know the increase in writing narrative paragraphs and paragraphs of narrative writing enhancement after using brainstorming strategies X5 grade students of SMA Negeri 1 Watansoppeng. The study motivated by the fact finding that the ways in which teachers have not been up on learning to write and 2-3 is only able to activate the students so that the learning process is not optimal. Therefore, the alternatives offered teaching writing by using brainstorming strategies. The study found: (1) The process of writing a narrative paragraph that dtunjukkan increase in activity of students in all learning kangkah. (2) Improve the writing paragraph narrative results by looking at changes in the average value obtained in the first cycle of students achieving an average score group $71.31 \%$ and in the second cycle increased to $82.24 \%$. the summery of the the study found that using Brainstorming proved significant in improving the ability of writing paragraphs X5 grade students of SMA 1 Watansoppeng.
\end{abstract}

Keywords: Narrative Paragraph Writing Ability, Strategy Brainstorming

\begin{abstract}
Abstrak
Penelitian tindakan kelas ini bertujuan untuk mengetahui peningkatan menulis paragraf narasi dan peningkatan hasil menulis paragraf narasi setelah menggunakan strategi brainstorming pada siswa kelas X5 SMA Negeri 1 Watansoppeng.Penelitian ini dilatarbelakangi oleh kenyataan yang dijumpai di lapangan bahwa cara yang digunakan guru belum maksimal pada pembelajaran menulis dan hanya mampu mengaktifkan 2-3 orang siswa sehingga proses pembelajaran belum optimal. Oleh sebab itu, alternatif penyelesaian masalah yang ditawarkan adalah pengajaran menulis dengan menggunakan strategi brainstorming. Penelitian ini menemukan: (1) Proses menulis paragraf narasi mengalami peningkatan yang dtunjukkan pada keaktifan siswa dalam semua kangkah pembelajaran.(2) Meningkatkan hasil menulis paragraf narasi dengan melihat perubahan nilai rata-rata yang diperoleh siswa pada siklus pertama mencapai skor rata-rata kelompok $71,31 \%$ dan pada siklus kedua mengalami peningkatan menjadi 82,24 \%. Dengan demikian dapat disimpulkan bahwa penerapan Strategi Brainstorming terbukti signifikan dalam meningkatkan kemampuan menulis paragraph siswa kelas X5 SMA Negeri 1 Watansoppeng.
\end{abstract}

\section{Kata Kunci: Kemampuan Menulis Paragraf Narasi, Strategi Brainstorming}

\section{PENDAHULUAN}


Menulis adalah menuangkan diri seseorang sehingga menumbuhkan gagasan, pendapat, perasaan, keinginan, keinginan untuk melatih diri dalam kemauan, dan informasi di dalam tulisan dan menuliskan gagasan yang ada dalam kemudian mengirimkannya kepada orang lain pemikiran individu. Keterampilan menulis (Syafi'ie, 1998:48). Kegiatan menulis sering dikatakan keterampilan yang paling bertujuan agar seorang penulis mampu kompleks dan bersifat ekspresif, misalnya menyampaikan informasi, mengemukakan pada sebuah karangan terutama karangan pendapat, menjelaskan sesuatu, narasi. Menulis karangan narasi harus menggambarkan sesuatu yang berupa hal menggunakan kata-kata yang saling atau kejadian, mengekspresikan perasaan dan berhubungan, penyusunan kalimat yang satu sebagainya melalui tulisan. Bahkan, setiap tidak terlepas dengan kalimat yang lainnya, penulis dapat menentukan sendiri tujuannya sehingga membentuk suatu paragraf yang dalam menulis.

utuh, paragraf demi paragraf tersusun

Tujuan pembelajaran menulis di dengan benar sehingga membentuk karangan sekolah adalah untuk membina siswa agar yang baik dan tidak menimbulkan keraguan mereka memiliki kemampuan dan makna.

keterampilan yang baik dalam menulis. Siswa diharapkan mampu menuangkan ide, gagasan, dan pendapat dengan baik dan benar, agar nantinya pembaca mampu menafsirkan pesan yang disampaikan penulis.

Pembelajaran menulis memiliki trik-trik untuk menyiasati agar kegiatan menulis ini menjadi lebih mudah. Oleh karena itu, dalam hal menulis seseorang harus mempunyai keterampilan tertentu agar tulisan yang dihasilkan bermutu. Menurut Syafi'ie (1998:45-47), untuk menghasilkan tulisan yang baik, seseorang perlu memerhatikan beberapa langkah yaitu (1) kemampuan menemukan masalah yang akan ditulis;(2) kepekaan terhadap kondisi pembaca;(3) menyusun perencanaan tulisan;(4) kemampuan memulai tulisan; dan(5) kemampuan memeriksa naskah karangan sendiri.

Kemampuan menulis karangan tidak akan terjadi dengan sendirinya, tapi memerlukan pembinaan dan latihan terus menerus, berkesinambungan, dan dilakukan sebagai proses pengembangan. Agar tujuan menulis karangan narasi itu tercapai dengan baik, maka pengajaran menulis karangan narasi harus diupayakan untuk dilakukan secara bertahap dan berencana.

Untuk menulis suatu paragraf narasi diperlukan ide (gagasan).Tidak ada satu paragraf narasi tanpa adanya gagasan.Gagasan adalah esensi dari nilainilai yang hendak ditawarkan penulis kepada pembaca.Makin rajin seseorang menulis, makin mudah mendapatkan ide untuk karyakaryanya.Agar sumber ide tidak kunjung habis, penulis juga perlu menimba ide-ide dari literatur yang luas.

Keterampilan menulis memegang gagasan hebat itu datang bagaikan kilat. peranan penting dalam kehidupan sehari-hari. Gagasan yang bagus kadang datang tidak Oleh karena itu, menulis sering digunakan terduga.Gagasan itu bisa muncul di saat dalam menyatakan gagasan atau pikirannya kapan pun dan dimana pun.Sepertinya, dengan tulisan atau karangan. Keterampilan seorang penulis tidak hanya menunggu lantas menulis berkembang melalui latihan. Adanya memperoleh gagasan hebat begitu saja.Perlu kemampuan menuangkan gagasan diawali ada pengondisian tertentu atau senantiasa dengan munculnya suatu kegemaran dalam 
menyiapkan diri dalam menangkap gagasan hebat dan kemudian memunculkannya.

Munculnya suatu gagasan dapat diibaratkan sebuah kendi.Kendi yang diibaratkan sebagai tempat air yang setiap saat bisa ditumpahkan menjadi sebuah gagasan yang memikat. Sebuah kendi tidak akan pernah mengeluarkan air manakala tidak pernah diisi air. Air itu ibarat gagasangagasan yang kita dapat dari membaca, mengamati, mendengarkan dan lain-lain. Artinya, dalam mengungkapkan sebuah gagasan yang baik diperlukan latihan secara bertahap dan diimbangi dengan literatur dan informasi yang ada (Nurudin, 2010: 6-10).

Menulis gagasan dalam bentuk paragraf narasi merupakan kompetensi dasar yang terdapat dalam Kurikulum Tingkat Satuan Pendidikan (KTSP). Penuangan gagasan tidak terjadi begitu saja tanpa suatu proses dan latihan dalam mengungkapkan ide yang ada dalam pikiran siswa. Keterampilan dalam menulis gagasan sering kali terhambat oleh kurang tepatnya strategi yang digunakan guru dalam proses belajar mengajar sehingga berdampak pada kurangnya motivasi, minat, dan pembiasaan siswa untuk menuliskan gagasannya.

Melihat kondisi realitas yang terjadi di SMA Negeri 1 Watansoppeng, sesuai dengan hasil observasi awal peneliti dan keluhan yang diungkapkan oleh salah seorang guru bahwa metode atau strategi yang lazim digunakan adalah metode diskusi kelompok, partisipatori, ceramah, dan lainlain. Metode ini hanya mampu mengaktifkan 2-3 orang siswa yang pada dasarnya siswa tersebut dari awal memang memiliki kemampuan dan kepercayaan diri dalam mengungkapkan ide atau gagasannya di depan kelas. Hal inilah yang mendorong peneliti untuk memulai tahap penuangan gagasan dalam bentuk tulisan agar siswa terbiasa dan terlatih dalam mengungkapkan gagasan, khususnya dalam bentuk paragraf narasi.

peneliti menawarkan satu solusi dalam permasalahannya.Adapun solusi yang ditawarkan adalah penggunaan strategi pembelajaran brainstorming. Brainstorming merupakan kegiatan berpikir berdasarkan asosiasi yang bebas dalam menemukan halhal apa saja yang berkaitan dengan perihal pokok karangan. Kegunaan brainstorming gagasan agar siswa dapat melakukan penulisan dengan mudah dan lebih terbantu dalam proses penulisan selanjutnya.

Berdasarkan uraian yang dikemukakan di atas, peneliti merasa perlu melakukan tindakan dalam upaya memperbaiki pembelajaran menulis paragraf narasi. Dalam hal ini, peneliti melakukan penelitian tindakan kelas dengan judul "Peningkatan Kemampuan Menulis Paragraf Narasi dengan Menggunakan Strategi Brainstorming Siswa Kelas X 5 SMA Negeri 1 Watansoppeng".

Berdasarkan latar belakang masalah yang telah diuraikan di atas, masalah yang dirumuskan adalah 1) apakah strategi brainstorming dapat meningkatkan proses menulis paragraf narasi siswa kelas X5 SMA Negeri 1 Watansoppeng? 2) apakah strategi brainstorming dapat meningkatkan hasil menulis paragraf narasi siswa kelas X5 SMA Negeri 1Watansoppeng?

Sesuai dengan rumusan masalah, maka tujuan penelitian ini yaitu 1) untuk mendeskripsikan peningkatan kemampuan siswa dalam proses menulis paragraf narasi dengan menggunakan strategi brainstorming siswa kelas X5 SMA Negeri 1 Watansoppeng. 2) untuk mengetahui peningkatan hasil menulis paragraf narasi dengan menggunakan strategi brainstorming siswa kelas X5 SMA Negeri 1 Watansoppeng. 
Penelitian ini diharapkan dapat dijadikan acuan atau pedoman bagi lembaga atau guru untuk menggunakan strategi pembelajaran brainstorming dalam mengajarkan menulis paragraf khususnya menulis paragraf narasi.

\section{METODE}

Berdasarkan judul penelitian ini, yakni "Peningkatan Kemampuan Menulis Paragraf Narasi dengan menggunakan Strategi BrainstormingSiswa Kelas X 5 SMA Negeri 1 Watansoppeng", maka penelitian ini digolongkan ke dalam penelitian tindakan kelas (classroom action research). Penelitian tindakan ini dilakukan untuk menggambarkan dan mengamati proses belajar siswa kelas X 5 SMA Negeri 1 dengan menggunakan strategi brainstorming. Mekanisme pelaksanaannya dengan dua siklus. Setiap siklus masing-masing dilaksanakan dengan empat tahap, yaitu:(1) Perencanaan, (2) Tindakan, (3)
Pengamatan, dan (4) Refleksi. Penelitian tindakan kelas ini merupakan salah satu upaya untuk memperbaiki praktik pembelajaran agar lebih bermanfaat.Dengan demikian, guru dapat mengetahui secara jelas masalah-masalah yang ada di kelas dan solusi dalam mengatasi masalah tersebut.

Jenis penelitian yang digunakan dalam penelitian ini adalah penelitian tindakan kelas dengan pemaparan data deskriptif kualitatif dan data kuantitatif.Data kualitatif diperoleh dari lembar observasi, lembar catatan lapangan, dan wawancara dalam setiap pelaksanaan tindakan (proses pembelajaran), dan data kuantitatif diperoleh dari tes akhir setiap siklus.

PTK terdiri atas rangkaian empat kegiatan yang dilakukan dalam siklus berulang.Empat kegiatan utama yang ada pada setiap siklus, yaitu (1) Perencanaan, (2) Tindakan, (3) Pengamatan (observation), dan (4) Refleksi.

Siklus dalam PTK dapat digambarkan sebagai berikut:

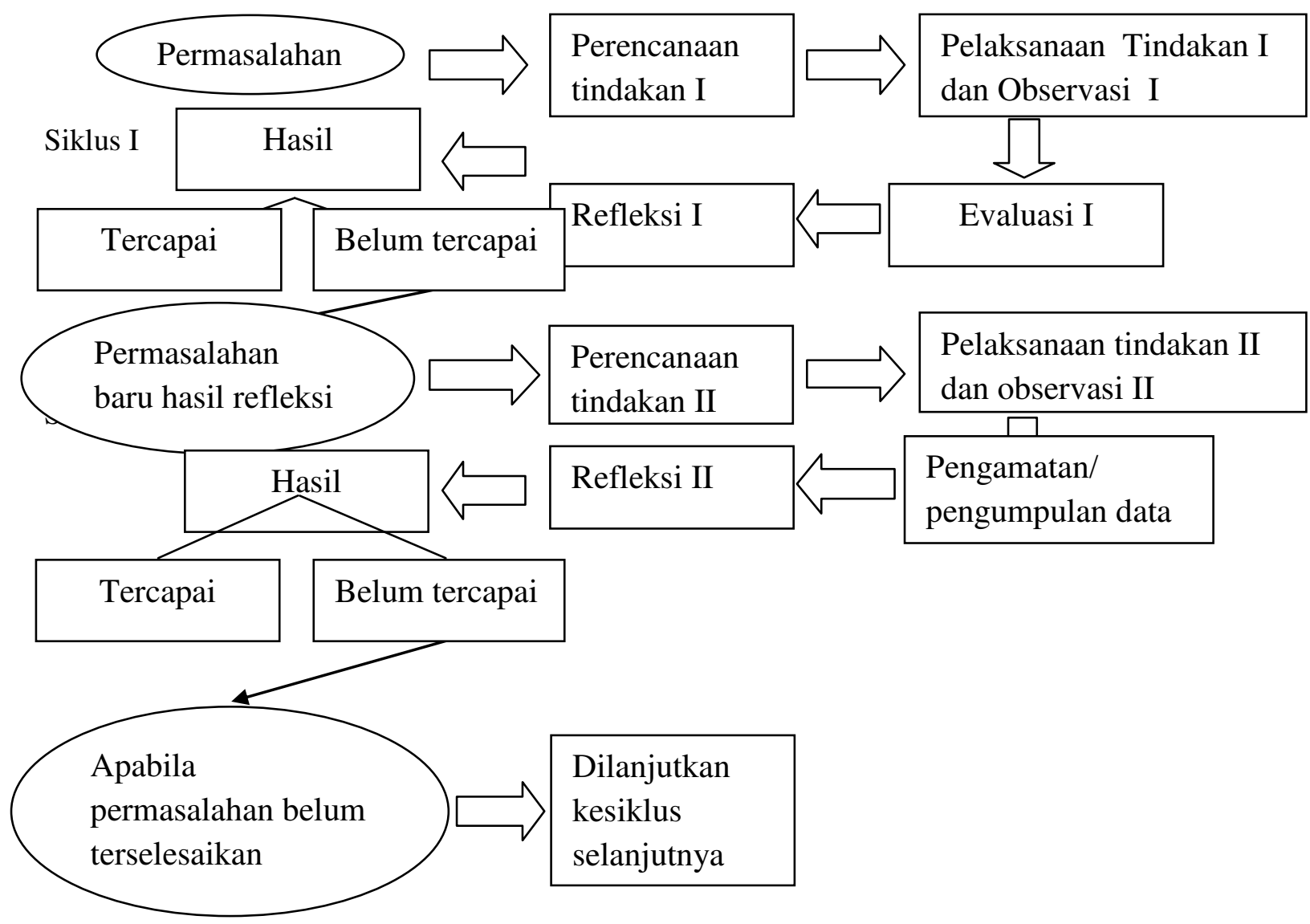


Penelitian ini adalah penelitian tindakan kelas yang dilaksanakan di kelas $\mathrm{X}$ semester 1 (ganjil) di SMA Negeri 1 Watansoppeng. Adapun Subjek dalam penelitian ini adalah siswa kelas X 5 , yang jumlahnya 33 orang.

Data penelitian ini berupa data perencanaan, data pelaksanaan, data evaluasi, dan data hasil. Data penelitian itu diperoleh melalui observasi, studi dokumentasi,dan tes dari setiap tindakan perbaikan penggunaan strategi brainstorming dalam pembelajaran menulis paragraf narasi bagi siswa kelas X 5 SMA Negeri 1 Watansoppeng. Data tersebut yaitu 1) data perencanaan berupa rancangan pembelajaran guru.Rancangan tersebut meliputi rumusan tujuan pembelajaran, penyusunan kegiatan belajar-mengajar, materi dan sumber belajar, pemilihan media, dan perencanaan evaluasi, 2) data pelaksanaan berkaitan dengan penerapan strategi brainstorming dalam pembelajaran menulis paragraf narasi yang dilakukan mulai dari tahap pramenulis, saat menulis, dan publikasi. Data tersebut berdasarkan hasil observasi, wawancara, dan catatan lapangan mengenai pengamatan tentang kegiatan siswa yang dibimbing guru selama proses pembelajaran menulis paragraf narasi berlangsung hingga guru dan siswa melakukan evaluasi terhadap hasil tulisannya.3) data evaluasi meliputi data proses dan data produk. Data proses dilakukan dengan cara mengobservasi kegiatan siswa selama mengikuti pembelajaran dari tahap pramenulis, menulis, dan publikasi. Sedangkan data produk berupa hasil gagasan dalam bentuk paragraf narasi setelah mengikuti proses pembelajaran menulis dengan penggunaan strategi brainstorming.
Sumber data dalam penelitian ini ada, 2 yaitu sumber data lisan dan tertulis. Sumber data lisan adalah informan yang memiliki pengetahuan tentang cara kerja siswa dalam hal ini guru. Sedangkan, sumber data tertulis adalah hasil kerja siswa yang berjumlah tiga puluh tiga orang.

Penelitian tindakan kelas ini direncanakan dalam 2 (dua) siklus. Siklus pertama berlangsung dalam 2 (dua) kali pertemuan dan siklus II juga berlangsung 2 (dua) kali pertemuan. Siklus I dan siklus II meliputi; perencanaan tindakan, pelaksanaan tindakan, pengamatan, dan refleksi.

$$
\text { Pelaksanaan untuk siklus I }
$$

berlangsung 1 (satu) kali pertemuan untuk pelaksanaan tindakan, dan 1 (satu) kali pertemuan untuk pelaksanaan tindakan sekaligus tes akhir siklus. Dalam siklus I strategi brainstorming, meliputi; (a) listing,(b) freewriting, dan (c) clustering.

Pada tahap perencanaan siklus I dilakukan yaitu 1) mengidentifikasi faktor penghambat dan pendukung yang dihadapi guru berdasarkan hasil observasi awal peneliti dalam pembelajaran menulis paragraf narasi dengan penerapan metode yang lazim digunakan pada saat mengajar menulis, khususnya dalam bentuk paragraf narasi. 2) merumuskan alternatif tindakan pembelajaran dengan menerapkan suatu strategi alternatif dari strategi yang lazim dan sebagai upaya untuk meningkatkan keterampilan siswa menulis paragraf narasi.menyusun rancangan tindakan selanjutnya sesuai hasil identifikasi terhadap strategi yang lazim digunakan dengan menawarkan strategi brainstorming yang meliputi: (a) kelas dibagi kelompok, (b) 
masing-masing kelompok dibagi ke dalam 56 orang, (c) siswa membuat daftar kata-kata berupa frasa atau kalimat dari satu topik yang telah ditentukan oleh guru, (d) siswa mengelompokkan daftar kata-kata tersebut ke dalam tiga bagian yang memiliki keterkaitan satu sama lain, (e)siswa memilih dan melingkari gagasan yang bisa mewakili dari setiap bagian untuk dijadikan topik utama tiap kelompok, (f) setiap siswa mengembangkan topik tersebut menjadi sebuah gagasan dan ditulis dalam bentuk paragraf narasi.

Pelaksanaan tindakan adalah guru melaksanakan pembelajaran sesuai Rencana Pelaksanaan Pembelajaran (RPP) yang telah dibuat dengan strategibrainstorming.Pelaksanaan

observasi menggunakan lembar observasi berupa pengamatan terhadap kehadiran, keaktifan dalam proses pembelajaran, melaksanakan strategi sesuai langkahlangkah brainstorming, perhatian atau konsentrasi, keaktifan selama proses pembelajaran, kelengkapan catatan, dan keaktifan dalam menulis paragraf narasi. Hasil tindakan dievaluasi dengan tes harian dan tes hasil belajar siklus I.

Peneliti mendiskusikan dengan guru hasil pengamatan tindakan yang telah dilaksanakan. Hal-hal yang didiskusikan adalah (1) menganalisis dan menjelaskan hasil yang diperoleh pada tindakan yang baru dilakukan, (2) menetapkan kesimpulan tentang hasil yang dicapai dalam peningkatan keterampilan menulis paragraf narasi siswa berdasarkan strategi brainstorming.Hasil refleksi dijadikan sebagai masukan pada tindakan selanjutnya (siklus kedua apabila hasil yang diperoleh kurang maksimal.

Siklus kedua,berdasarkan hasil refleksi pada siklus pertama, maka pada tahap ini peneliti mengidentifikasi kembali faktor-faktor yang menghambat guru dalam proses pembelajaran menulis pada siklus pertama, merumuskan alternatif tindakan lanjutan dalam meningkatkan proses pembelajaran menulis paragraf narasi. merevisi skenario pembelajaran menulis dan selanjutnya menyusun kembali rancangan tindakan pembelajaran menulis. menyempurnakan panduan pembelajaran menulis berdasarkan hasil refleksi siklus 1 sehingga siswa memiliki rasa kepercayaan diri dan meningkatkan kemampuan berpikir kritis dalam mengonstruksi sendiri pengetahuan baru tentang menulis berdasarkan pengetahuan dan pengalaman nyata mereka.

Pelaksanaan untuk siklus II berlangsung satu kali pertemuan untuk pelaksanaan tindakan, dan 1 (satu) kali pertemuan untuk pelaksanaan tindakan sekaligus pelaksanaan tes akhir siklus. Pada tahap ini peneliti melaksanakan tindakan pembelajaran menulissesuai dengan yang direncanakan dan melaksanakan pemantauan terhadap segala aspek yang mendukung dan menghambat pelaksanaan tindakan pembelajaran menulis paragraf narasi tersebut. Pelaksanaan observasi dan evaluasi pada siklus II, hampir sama dengan siklus I. Pada tahap ini dilakukan observasi dan tes akhir hasil belajar . Hasil pengamatan tindakan yang telah dilaksanakan dianalisis dan ditetapkan kesimpulan tentang hasil yang dicapai dalam peningkatan keterampilan menulis paragraf narasi dengan menggunakan strategi brainstorming .

Teknik pengumpulan data yang digunakan dalam penelitian ini adalah teknik dokumentasi, teknik observasi, teknik wawancara, dan teknik analisis teks (latihan).Data yang terkumpul berupa data hasil observasi, catatan lapangan, wawancara, tentang proses pembelajaran menulis paragraf narasi dengan strategi brainstorming, serta hasil tulisan siswa. Data tersebut direduksi berdasarkan 
masalah yang diteliti, diikuti penyajian data, dan terakhir penyimpulan atau verifikasi. Langkah analisis ini dilakukan berulang-ulang.

Penerapan strategi pembelajaran brainstorming dalam upaya meningkatkan keterampilan menulis gagasan dalam bentuk paragraf narasi pada siswa kelas X 5 SMA Negeri 1 Watansoppeng dikaitkan dengan ketuntasan belajar. Siswa yang mendapatkan nilai $75 \%$ ke atas maka strategi pembelajaran brainstorming oleh guru dapat berhasil efektif.

Tabel Taraf keberhasilan yang dicapai siswa dikatakan berhasil apabila mencapai nilai baik dan sangat baik

\begin{tabular}{|l|l|l|}
\hline NO & Interval Nilai & Tingkat Kemampuan \\
\hline 1. & $91 \%-100 \%$ & sangat tinggi \\
2. & $76 \%-89 \%$ & tinggi \\
3. & $65 \%-75 \%$ & sedang \\
4. & $41 \%-64 \%$ & rendah \\
5. & $0-40 \%$ & sangat rendah \\
\hline
\end{tabular}

(Nurgiyantoro, 1995)

Kemampuan siswa dalam menulis paragraf narasi didasarkan pada lima hal pokok, yaitu kesatuan isi, koherensi, penggunaan EYD, pemanfaatan referensi, kronologis waktu dan tempat

\section{PEMBAHASAN}

Permasalahan utama penelitian ini adalah usaha untuk meningkatkan kemampuan menulis paragraf narasi dengan menggunakan strategi brainstorming.Timbulnya permasalahan ini dilatarbelakangi oleh permasalahan teoretis dan permasalahan praktis. Permasalahan teoretisnya adalah dalam proses pembelajaran hanya menekankan pada pembelajaran yang bersifat hasil, tanpa memperhatikan segi proses pembelajaran yang berlangsung di kelas. Akibatnya, di kelas tidak terjadi interaksi aktif antara guru dan siswa dalam menyelesaikan tugas menulisnya, khususnya menulis paragraf narasi.Adapun permasalahan praktisnya adalah adanya kenyataan bahwa pembelajaran menulis pada umumnya dan menulis paragraf narasi pada khususnya tidak disenangi oleh siswa. Hal ini berdasarkan pada situasi pembelajaran yang tidak kondusif dan cara guru mengajarkan keterampilan menulis yang tidak memberikan motivasi sehingga tidak menarik minat siswa untuk menyenangi pembelajaran tersebut agar mereka terbiasa dalam mengungkapkan gagasannya dalam bentuk tulisan.

Proses Penggunaan Strategi Brainstorming dalam Pembelajaran Menulis Narasi

Proses penggunaan strategi brainstorming dalam pembelajaran menulis narasi diawali dengan menyampaikan tujuan pembelajaran dan memberi motivasi belajar kepada siswa untuk mengetahui tujuan pembelajaran yang akan mereka ikuti sehingga pemikiran siswa tidak mengambang dan terfokus pada pembelajaran menulis narasi. 
Kegiatan selanjutnya adalah guru menyajikan informasi pembelajaran kepada siswa. Pada kegiatan ini, guru menyampaikan materi pembelajaran dan tugas-tugas yang akan diselesaikan oleh siswa pada saat proses pembelajaran berlangsung. Kegiatan yang dilakukan oleh siswa dalam proses pembelajaran dengan penggunaan strategi brainstorming, meliputi: (1) siswa menuliskan apa yang terpikirkan dalam benaknya mengenai topik yang telah disampaikan oleh guru dalam bentuk daftar kata atau frasa secara berkelompok; (2) masingmasing siswa menulis paragraf secara bebas berkaitan dengan daftar kata yang telah dibuat secara berkelompok; (3) siswa mengelompokkan kata atau frasa yang identik dalam tulisan bebas yang telah dibuatnya dalam kelompok masingmasing dengan menarik garis terhadap kolom yang saling berkaitan sehingga lebih menuntun dalam menulis paragraf narasi secara individu; dan (4) siswa menulis paragraf narasi.

Penggunaan strategi brainstorming dalam pembelajaran menulis paragraf narasi pada siklus pertama menekankan pada tiga langkah pembelajaran yaitu listing (membuat daftar kata atau frasa), freewriting (menulis bebas), dan clustering (mengelompokkan kata atau frasa). Setelah ketiga langkah pembelajaran tersebut terlaksana, tes akhir siklus dilaksanakan dengan memberikan tugas kepada siswa untuk menuliskan pengalamannya dalam bentuk paragraf narasi yang mengacu pada hasil pengelompokkan kata atau frasa (clustering) agar siswa lebih mudah dalam menulis kisah hidupnya dalam bentuk paragraf narasi.

Tahap listing memacu siswa untuk berpikir secara cepat mengenai topik yang telah ditentukan dan menuliskan apapun yang ada dalam pikiran. Langkah pembelajaran listing dikerjakan siswa secara berkelompok dengan mengisi lembar daftar yang telah disiapkan.

Tahap freewriting memberikan kesempatan kepada siswa untuk menuangkan gagasannya tanpa dibatasi oleh ketentuan bahwa harus menulis dengan bentuk paragraf apa saja. Hal ini menjadikan siswa terbiasa menuangkan ide maupun gagasan dalam bentuk tulisan untuk memotivasi siswa dalam menuli

Pada siklus pertama semua kelompok menulis daftar kata atau frasa dengan cepat, namun dimonopoli oleh siswa yang sudah terbiasa dan cepat dalam mengemukakan gagasan. Siswa yang memiliki kemampuan yang agak kurang dalam menulis tidak aktif sehingga nilai yang diperoleh tidak mencapai hasil maksimal. Hal ini ditunjukkan oleh kelompok I, hanya 2 orang saja yang aktif dalam kelompok tersebut. Pembagian kelompok secara heterogen dilakukan oleh guru tetapi secara tidak sengaja, beberapa siswa yang terbiasa aktif di dalam kelas tergabung dalam kelompok $\mathrm{V}$ sehingga kelompok inilah yang aktif dalam proses menulis hingga tes akhir siklus dan menunjukkan nilai yang maksimal.

Siklus kedua dilaksanakan sebagai hasil refleksi siklus yang pertama yaitu masih terdapat kelompok yang belum aktif dalam proses pembelajaran dan hasil yang dicapai pada akhir tes belum mencapai $75 \%$. Hal inilah yang menjadi acuan sehingga perlu dilanjutkan ke siklus kedua. Pelaksanaan pembelajaran sudah mampu mengaktifkan siswa dalam proses menulis paragraf narasi. Selain itu, siswa sudah mulai merasa terbiasa dengan kelompok masing-masing sehingga menimbulkan motivasi kepada siswa secara tidak langsung. Guru berperan dalam menyampaikan materi pembelajaran dan menghampiri siswa pada tiap kelompok sehingga memberikan kesempatan kepada siswa untuk bertanya secara langsung mengenai materi yang tidak dipahami. 
Tahap clustering dijadikan pemacu dalam menulis paragraf narasi, karena tahap ini tiap kata atau frasa dikelompokkan dengan menghubungkan garis pada kata atau frasa yang memiliki keterkaitan satu sama lain. Dalam hal ini, siswa lebih mudah memfokuskan paragraf berdasarkan kronologis waktu dan tempat.

Hasil analisis tes akhir siklus pertama ditunjukkan dalam tabel

Skor dan Nilai Menulis Paragraf Narasi Secara Berkelompok Siswa Kelas X 5 SMA Negeri 1 Watansoppeng Siklus Pertama

\begin{tabular}{llllllll}
\hline \multirow{2}{*}{ No. } & Kelompok & \multicolumn{7}{l}{ Aspek yang Dinilai } & \multirow{2}{*}{ Nilai Akhir } \\
\cline { 3 - 6 } & & 1 & 2 & 3 & 4 & 5 & \\
\hline 1. & I & 72.22 & 72.22 & 66.67 & 75,00 & 58,33 & 68,89 \\
2. & II & 73,33 & 60,00 & 66,67 & 80,00 & 65,00 & 69,00 \\
3. & III & 66,67 & 72,22 & 72,22 & 83,33 & 62,50 & 71,39 \\
4. & IV & 72,22 & 66,67 & 72,22 & 70,00 & 66,67 & 69,56 \\
5. & V & 80,00 & 86,67 & 73,33 & 90,00 & 75,00 & 81,00 \\
6. & VI & 66,67 & 66,67 & 66,67 & 70,00 & 70,00 & 68,00 \\
\hline
\end{tabular}

Skor rata-rata $=71,31 \%$

Dari hasil penilaian berdasarkan interval nilai yang ditetapkan, 1 kelompok yang mendapatkan nilai di atas $75 \%$, dan 5 kelompok yang mendapatkan nilai di bawah 75\%. Kelompok V menunjukkan keaktifan dari awal pembelajaran hingga akhir siklus yang ditunjukkan pula pada hasil tes dengan nilai yang cukup maksimal. Namun, pada kelompok I,II, III, IV, dan VI memperoleh nilai akhir tes siklus yang tidak mencapai $75 \%$. Dalam proses pembelajaran ada beberapa siswa tidak berperan aktif dalam setiap langkah pembelajaran yang disampaikan oleh guru. Hal ini membuktikan bahwa lima kelompok belum mencapai target yang ditentukan yaitu nilainya masih di bawah $75 \%$, artinya strategi brainstorming dalam menulis paragraf narasi pada siswa kelas X 5 SMA Negeri 1 Watansoppeng pada siklus pertama belum berhasil dan akan diperbaiki pada siklus kedua. Sedangkan satu kelompok yang dinyatakan sudah berhasil dengan nilai di atas $75 \%$ dipertahankan pada siklus kedua

Hasil analisis tes akhir siklus kedua ditunjukkan dalam tabel

Tabel Skor Dan Nilai Menulis Paragraf Narasi Secara Berkelompok Siswa Kelas X 5 SMA Negeri 1 Watansoppeng Siklus Kedua

\begin{tabular}{|c|c|c|c|c|c|c|c|}
\hline \multirow{2}{*}{ No. } & \multirow[t]{2}{*}{ Kelompok } & \multicolumn{5}{|c|}{ Aspek yang Dinilai } & \multirow{2}{*}{ Nilai Akhir } \\
\hline & & 1 & 2 & 3 & 4 & 5 & \\
\hline 1. & I & 83.35 & 77,78 & 72,25 & 83,33 & 75,00 & 77,09 \\
\hline 2. & II & 86,67 & 73,34 & 80,00 & 90.00 & 75,00 & 78,75 \\
\hline 3. & III & 83.35 & 88,89 & 88,89 & 91,67 & 75,00 & 86,11 \\
\hline 4. & IV & 88,89 & 72,22 & 83,33 & 83,33 & 79.16 & 81,94 \\
\hline 5. & $\mathrm{~V}$ & 93,33 & 93,33 & 86,67 & 90,00 & 85,00 & 89,22 \\
\hline 6. & VI & 86,67 & 73,33 & 73,33 & 83,33 & 85,00 & 80,33 \\
\hline
\end{tabular}


Skor rata-rata $=82,24 \%$

Uraian table di atas mengenai aspek yang dinilai dari hasil tes menulis paragraf narasi siswa kelas X 5 SMA Negeri 1 Watansoppeng dijabarkan sebagai berikut:

Keaktifan siswa dalam melaksanakan semua langkah pembelajaran yang telah disampaikan oleh guru terlihat pada semangat siswa yang sudah memahami materi dan sudah merasa terbiasa berbagi pendapat dengan teman kelompok menjadikan proses pembelajaran berlangsung dengan lancar. Pelaksanaan tes akhir siklus kedua menunjukkan peningkatan mengenai hasil menulis paragraf narasi siswa kelas X 5 SMA Negeri 1 Watansoppeng.

Dari hasil penilaian berdasarkan interval nilai yang ditetapkan,kelompok I memperoleh nilai 77,09, kelompok II memperoleh nilai 78,75, kelompok III memperoleh nilai 86,11, kelompok IV memperoleh nilai 81,94, kelompok V memperoleh nilai 89,22, dan kelompok VI memperoleh nilai 80,33. Seluruh kelompok mendapatkan nilai di atas 75\%. Tidak ada kelompok yang mendapatkan nilai di bawah $75 \%$, artinya strategi brainstorming dalam menulis paragraf narasi pada siswa kelas X 5 SMA Negeri 1 Watansoppeng dapat dinyatakan berhasil.

\section{KESIMPULAN DAN SARAN}

\section{Kesimpulan}

Berdasarkan hasil penelitian maka kesimpulan yang dapat diperoleh adalah kemampuan siswa dalam menulis paragraf narasi siswa kelas $X \quad 5 \quad$ SMA Negeri 1 Watansoppeng tahun pelajaran 2013/2014 mengalami peningkatan setelah penerapan strategi brainstorming, dengan indikasi yaitu 1) proses menulis paragraf narasi mengalami peningkatan setelah adanya penerapan strategibrainstorming yang ditunjukkan pada keaktifan siswa dalam semua langkah pembelajaran. 2) penerapan strategi brainstorming dapat meningkatkan hasil menulis paragraf narasi dengan melihat perubahan nilai rata-rata yang diperoleh siswa pada siklus pertama yang mencapai skor ratarata nilai kelompok $71,31 \%$ (dilanjutkan ke siklus II karena masih terdapat kelompok yang belum mencapai nilai rata-rata minimal yaitu 75 $\%$ sehingga menjadi bahan refleksi untuk dilanjutkan ke siklus II) hingga pada siklus kedua mengalami peningkatan menjadi 82,24 \%.

\section{Saran}

Berdasarkan hasil penelitian saran-saran yang dapat diajukan yaitu 1) guru kelas X 5 SMA Negeri 1 Watansoppeng dapat mengarahkan siswa untuk mengoptimalkan keterampilannya dalam menulis paragraf narasi dengan menerapkan strategi brainstorming dalam proses pembelajaran sehingga dapat menumbuhkan keinginan dan motivasi terhadap siswa.2) Guru kelas X 5 SMA Negeri 1 Watansoppeng dapat memberikan motivasi secara langsung bagi siswa yang masih pasif pada saat proses pembelajaran sehingga menumbuhkan kepercayaan diri dalam mengemukakan gagasannya. 3) pengetahuan dan pengalaman guru kelas X 5 SMA Negeri 1 Watansoppeng dalam penerapan strategi brainstorming di kelas dapat lebih ditingkatkan dengan mengikuti berbagai pelatihan dan lebih memperbanyak referensi mengenai strategi brainstorming sehingga dalam penerapannya dapat menjadikan siswa lebih kreatif dalam menulis khususnya paragraf narasi.

\section{DAFTAR PUSTAKA}

Arikunto, Suhardjono. Suharsimi. 2009. Penelitian Tindakan Kelas. Jakarta: Bumi Aksara.

Enre, Fachruddin Ambo. 1994. Dasar-dasar Keterampilan Menulis. Ujung Pandang: IKIP UJungpandang. 
Gunawan, dkk. 1997. Belajar Mengarang: Dari Muslich, Masnur. 2011. KTSP: Pembelajaran Narasi hingga Argumentasi. Jakarta: Berbasis Kompetensi dan Kontekstual. Erlangga Jakarta: Bumi Aksara.

Johnson, David W. 2010. Colaborative Learning: Nurgiyantoro, Burhan. 1995. Penilaian Pengajaran Strategi Pembelajaran untuk Sukses Bahasadan Sastra. Yogyakarta: BPEE. Bersama. Bandung: Nusa Media

Nurudin. 2007. Dasar-dasar Penulisan. Malang: Keraf, Gorys. 2007. Argumentasi dan Narasi. Universitas Negeri Malang. Jakarta: Gramedia Pustaka Utama.

Roestiyah. 2008. Strategi Belajar Mengajar. Jakarta: Rineka Cipta. 